\title{
Hoax and The Principle of Legal Certainty in Indonesian Legal System
}

\author{
Sholahuddin Al-Fatih ${ }^{1}$, Zaka Firma Aditya ${ }^{2}$ \\ \{ salfatih@umm.ac.id ${ }^{1}$, zaka.firma@mkri.id ${ }^{2}$ \} \\ Faculty of Law, University of Muhammadiyah Malang, Malang, Indonesia ${ }^{1}$, Center for Research and \\ Case Analyse - Constitutional Court of The Republic of Indonesia, Jakarta, Indonesia ${ }^{2}$
}

\begin{abstract}
There is no doubt that legal certainty is one of the basic principles in a lawbased society. In fact, it can also be said that the principle of legal certainty is often considered synonymous with the rule of law itself. Thus, the principle of legal certainty has reached the character of universality. Problems arise when the principle of legal certainty is confronted in a concrete case. In the case of the spread of HOAX, for example, the principle of legal certainty is more widely used than the principle of legal justice. As a result, at present, many people are subjected to criminal penalties because law enforcers, especially court judges, prioritize legal certainty (as written in the law) rather than applying legal justice. In this case, this article will discuss critically the application of the principle of legal certainty in the Indonesian legal system. In particular, this article highlights the fact that in many cases the spread of deception, judges prioritize the approach of using the principle of legal certainty rather than seeking substantive legal justice from the case.
\end{abstract}

Keywords: Legal Certainty, Hoax, Law, Case, Justice.

\section{Introduction}

The use of social media is currently growing very rapidly. The ease and efficiency that offered by social media, especially those based online are making it a forum for disseminating information that is very influential in society. Media social not only changed the way of information delivery but also changed the insight of people that consume information. These spectacular developments also have an impact on the development of legal interactions and social interactions. Besides giving positive impacts in the form of ease of interaction that is not limited to time and space, information technology media also has negative impacts on its users. Problems that often occur are the absence of control and tend to be misused for acts of crime such as human trafficking, the spread of hoax news, provocation, slander, hacking, data breach especially banks, and other cyber crimes [1].

One of the biggest impacts of the development of social media is the incessant spread of hoax news. Because, dissemination of information or news through online media recent is not only done by a news site that is already known by the public, but by anyone as internet users can contribute to the dissemination of information. Unfortunately, a lot of information and news distributed individually or in groups more unaccountable their truth or hoax indication. Hoax is information or news that contains things that are uncertain or which are not facts that occur. In the view of Tarlach McGonagle in his article entitled Fake News: False Fears or Real 
Concern defines hoax or false news as information that has been deliberately fabricated and disseminated with the intention to deceive and mislead others into believing falsehoods or doubting verifiable facts[2]. McGonagle further added that it was information that was presented as or is likely to be perceived as news. Unlike many other types of information, news plays a particular role in democratic societies: it is a key source of accurate information about political and societal affairs, which informs public opinion-making and deliberative processes[2].

In Indonesia, the hoax outbreak has become a national problem which has resulted in divisions, political instability, and security disturbances. Many cases of hoaxes that occurred in Indonesia triggered a wave of demonstrations and hostilities between groups, which resulted in national instability, especially nearing the political year. In 2016 for example, the case of the spread of hoax news through facebook by editing transcript of the incumbent governor Basuki Tjahja Purnama (Ahok) conducted by Buni Yani, triggered a wave of demonstrations 411 and 212. Millions of Muslims from all over Indonesia came to Jakarta and held demonstrations demanding the resignation of Basuki Tjahja Purnama for alleged blasphemy based on video spread by Buni Yani. This case resulted in political instability that is long enough, and the potential for unrest was very high ahead of Jakarta governor election and forced the government issued an emergency status for the capital, Jakarta. Although in the end, the two main actors in this case in prison based on the decision of judicial action. Ahok was sentenced to 1 year eight months for being proven to have committed blasphemy during the election campaign for the Governor of DKI Jakarta, and Buni Yani was sentenced to 1.5 years in jail for being proven to be editing videos and spreading them.

In addition, ahead of the 2019 general election, the public was also shocked by the hoax news spread by Ratna Sarumpaet as one of the sympathizers of supporters of the 2019 presidential candidate. Ratna Sarumpaet spread the news that she had been persecuted by supporters of an incumbent presidential candidate. Through a photo of himself with a bruised face because of being persecuted, Ratna managed to fool and even get sympathy from the elite politicians who supported the Presidential Candidate Couple. The photos and news were disseminated through social media and managed to make a public scene. In fact, the presidential candidates to make a press conference regarding the abuse case. Unfortunately, in the end, Ratna Sarumpaet admitted that the persecution case was a joke and humor made by himself. For his actions, Ratna was finally arrested by the Metro Jaya Regional Police and threatened with ten years imprisonment and expelled from members of the Prabowo-Sandi Winning Team.

From the above two phenomenal cases, it can be seen that the perpetrators of a hoax spreader increasingly facilitated due to lack of filtering of news on social media so any news in the post someone can easily spread. The presence of social media has a lot of positive effects, but there are not a few negative impacts. In Indonesia, the presence of social media also influences political, social, cultural, and economic changes in Indonesia. Social media shifts and penetrates the boundaries of hierarchical interaction patterns to be egalitarian, both in the political and cultural space. An ordinary citizen can directly criticize and communicate with the President simply by sending a mention to the President's account on Instagram. Information that is not even qualified is scattered massively without verification and confirmation. This is in line with Mastel Indonesia's (2017) national hoax outbreak survey that the most commonly used hoax news distribution channel in Indonesia is through social media $(92.40 \%)$ followed by Chat Applications (62.80\%), Website $(34.90 \%)$, Television (8.79\%), Print Media (5\%), Email (3.10\%) and Radio (1.20\%)[3]. The most frequent types of hoaxes 
received by the people of Indonesia is related to the social and political $(91.80 \%)$ and SARA $(88.60 \%)[3]$, furthermore can be seen in Figure 1 below:

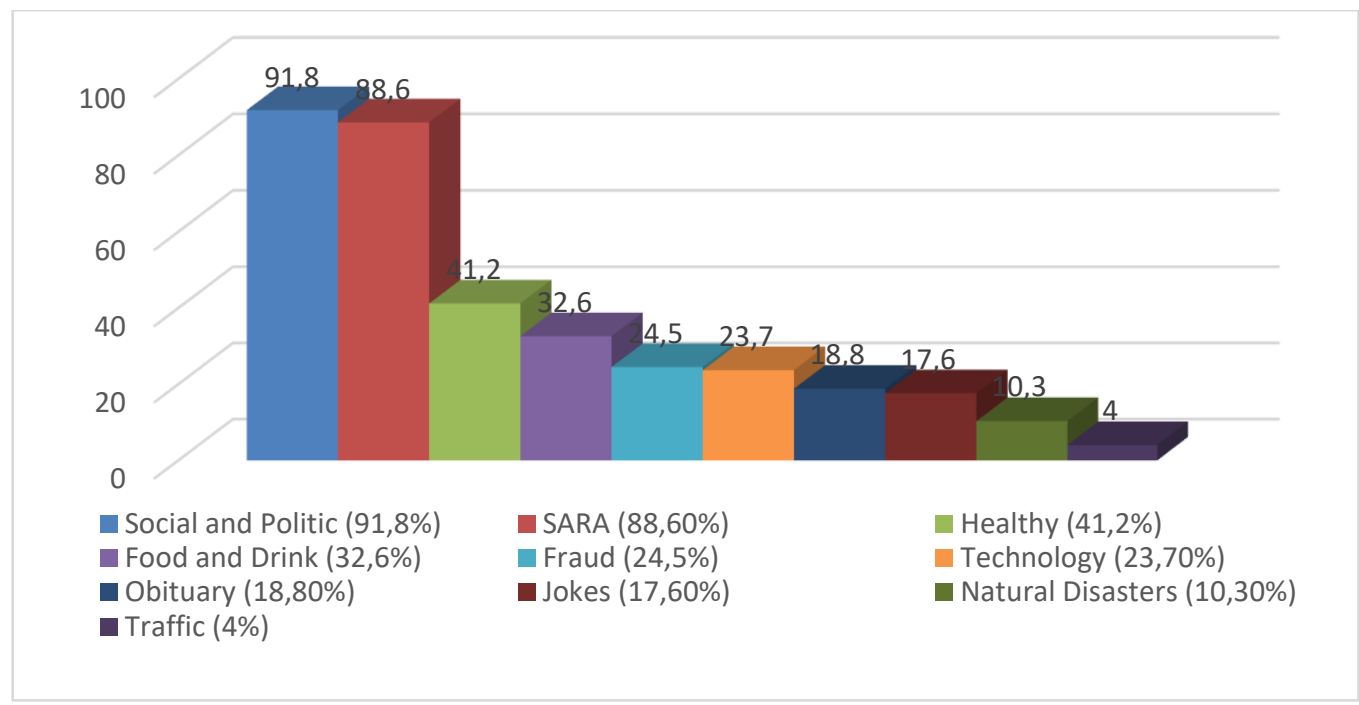

Fig 1. The types of a hoax that most commonly accepted by Indonesian people [3]

Actually, hoax cases are not only experienced in Indonesia. Allcott and Gentzkow (2017) have conducted research entitled Social Media and Fake News in the 2016 Election. This research concludes that social media platforms, such as Facebook have very different structures from previous media technology (mainstream media)[4]. Content on social media can be delivered between users without third-party filtering, fact-checking, or editorial assessment[4]. The average US adult reads and remembers the order of one or several fake news articles during the election period, with higher exposure to pro-Trump articles than proClinton articles[4]. From this study, it can be seen that the results of this election depend on the effectiveness of hoax exposure in changing the way people choose.

The question then is what about law enforcement? As we all know, the perpetrators of hoaxes are threatened with a high enough crime. In Indonesia, there are two (2) laws that can be used to punish the perpetrators of the spread of hoaxes, namely the Criminal Code and the Information and Electronic Transaction Law (IET Law) specifically Article 28 Paragraphs (1) and (2). I pulled him, in implementation, the judges more approach legal certainty than legal justice (substantive) in solving the case of a hoax. This can be seen the verdict imposed by the judge on the perpetrators of the hoax distribution whose verdict is almost the same as the demands of the prosecutor. Therefore, this paper will discuss in depth the implementation of the principle of legal certainty in the case of hoaxes in Indonesia. This discussion will be interesting because the number of cases of the spread of hoax news in Indonesia is captured using Article 28 of the IET Law which is basically a rubber article that can ensnare all circles of society. 


\section{Hoax and The Application of The Principle of Legal Certainty in The Indonesian Legal System}

\section{1. Hoax and Its Developments in Indonesia}

In the Oxford dictionary, the hoax is defined as a form of fraud whose purpose is to make humor or bring danger[5]. Hoax in Indonesian means false information or false news. Walsh, in his book entitled Against Science, The Scientific Media Hoaxes of Poe, Twain, and Others wrote that the term hoax had existed since 1800 early in the era of industrial revolution in England. The origin of the word hoax is believed to have existed for hundreds of years before, namely 'hocus' of the mantra 'hocus pocus', a phrase often referred to by magicians, similar to 'sim salabim' [6]. Indeed, Boese in his book Museum of Hoaxes writes that long before that, the term hoax was first published through a fake almanac made by Isaac Bickerstaff in 1709 to predict the death of astrologer John Partridge [7].

Moreover, hoax or fake news has also been deployed by States as a weapon in information and ideological warfare on the international plane, alongside the jamming of broadcast signals and, in recent years, the blocking of websites. This became a major preoccupation for the United Nations (UN) in the early days of the organization with the onset of the Cold War. The problem was framed in terms of the threat by systematic diffusion deliberately false or distorted reports[2].

In Indonesia, as explained earlier, the hoax spreader has been growing rapidly since 2012 . According to Andrea Renda, online smear campaigns in Indonesia since they have been standing in elections since 2012. Some of these politically motivated campaigns have been aided by well-organized "fake news factories" such as the Saracen Cyber Team, the online syndicate that created many social media accounts to spread hate speech for clients willing to pay for them. Online narrative narratives have polarized public opinion in the lead-up to the Jakarta governorial elections in 2017 that saw the defeat of former governor, Basuki Tjahaja Purnama. The Indonesian government hence has beefed up existing not only by introducing new provisions but also by the issuing guidelines to aid their implementation and enforcement of the Police Multimedia Bureau in 2017 [8].

Ironically, during 2018, there were several cases of the hoax is quite phenomenal in Indonesia. First, the Hoax aftershocks in Palu circulating through broadcast content through the Whatsapp Application about the aftershock in Palu is very disturbing to the people of Palu City in particular. The news had a direct impact on the victims of the earthquake and tsunami, which were still traumatized. Broadcast it is spread through the chain message is written that the Palu is on standby. Second, immunization and vaccines hoaxes. Immunization often gets a rejection from some community groups because of incomplete or incorrect information hoax. One of hoax about immunization vaccines which are quite viral are issues of conspiracy to spread viruses or diseases through vaccines. Reportedly vaccines used for immunization contain animal cells, viruses, bacteria, blood, and pus. This incorrect issue has had a tremendous impact on the stigma of the Indonesian people about Immunization. As a result, people become hesitant and even afraid to give immunizations to their children.

Third, hoax child abduction. Hoax child abduction circulates on social media such as Facebook, Twitter, and WhatsApp. This troubles the community, especially parents who have young children. In twitter, Hoax circulating stated that the kidnapping of children was caught on Jalan Kran Kemayoran, Central Jakarta. Fourth, Hoax Lion Air black box recording. Lion plane crash JT610 water is not released into materials hoax. One of them also circulating videos on the YouTube platform uploaded by channel Juragan Batik Reborn on October 29, 
2018, with the title "LION AIR JT610 is Horrible BLACK BOX Records". The video is not the contents of the recording from black box Lion Air JT610 but someone's response related to the MAP video Lion AIr JT610 seconds lost contact. So that the title of the content is not in accordance with its contents can be categorized as disinformation/hoax content.

Fifth, hoax marriage card with a photo of 4 wives. After the Ministry of Religion officially issued marriage cards for married couples for the efficiency and accuracy of data, viral circulation on social media was a picture of a yellow marriage card with the Ministry of Religion logo. In the card are listed four wife columns and one husband column complete with column names and wedding dates in each wife's column. This information Hoax. Sixth, flammable food hoaxes contain plastic. As early as 2018, the issue of the presence of hazardous substances in the powder of a coffee beverage brand appeared sachet. It was busy talking after uploading a video of someone spreading the coffee powder onto the fire, which makes the flame even bigger and grabs. Whereas BPOM, through its official website, provides an explanation that this cannot be justified. Seventh, telephone and WhatsApp hoaxes are tapped by the government. In the early 2018 news spread hoax through a broadcast message about monitoring all activities of mobile users. In fact, this information shows that cellphone users will be tapped and monitored by the State Cyber and Code Body (BSS N), even though this information hoax.

The number of hoaxes that occur due to the emergence of social media is not only used for merely socializing but also has become a means of exchanging information, doing business, campaigning, protesting, inviting demonstrations, even dating. The most influential social media, in this case, is Instagram and Facebook. Most people today at least will have one Instagram account and one Facebook account in the application they have on a mobile phone or smartphone. In fact, for some other people who run their online business, they will have more than one account in one type of social media. The number of accounts on social media will have implications for the faster the spread of content or information. Now it is not difficult to get information from various places even though the event just happened.

The next factor is the existence of a kind of euphoria in using the internet and social media. As we know before the reforms, people in Indonesia experienced limitations in expressing opinions and democracy. However, since the revolving reforms of the community seemed to get a fresh breeze to express their aspirations and opinions more freely regarding political, economic, social, and cultural issues, even everyday problems in their personal lives. Another problem that causes false or hoax information to be increasingly difficult to control is, there is a habit of most people who want to quickly share information. The Indonesian people do have the characteristics of 'like to tell stories' so that these qualities are also carried away in the way they communicate using social media. It often happens that the users of social media share information that they get without checking the truth. Based on the Mastel survey, at least $44.3 \%$ of the people received hoax news every day. More can be seen in figure 2. 


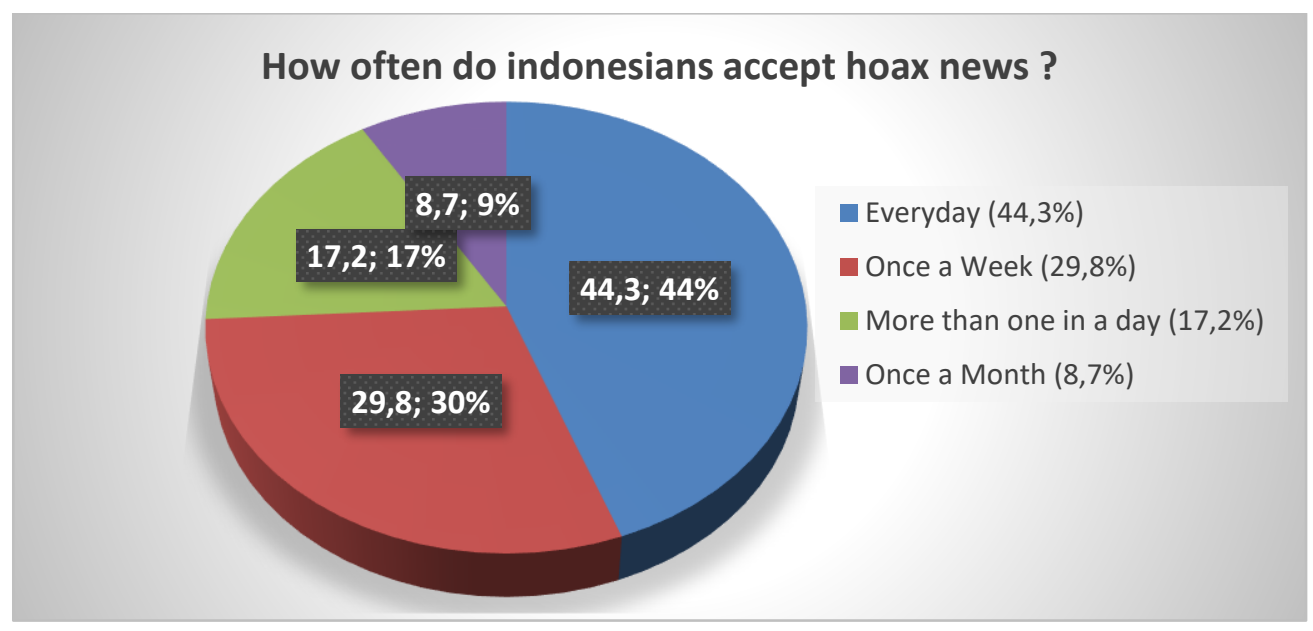

Fig 2. How Often Do Indonesians Accept Hoax News[3]

\subsection{The Application of The Principle of Legal Certainty in The Indonesian Legal System}

The principle of legal certainty has always been an interesting material to be debated at the level of legal philosophy, especially in countries that adhere to the civil law system such as Indonesia. This principle is a pragmatic question that can only be answered normatively, not sociologically. Normative legal certainty is when a rule is made and promulgated with certainty because it regulates a clear and logical way. That is, it does not cause doubt and is logical in the sense that it becomes a norm system, with other norms so that it does not clash or cause norm conflicts. The norm conflict caused by rule uncertainty can be in the form of norm contestation, norm reduction, or norm distortion.

In a country that adheres to the Civil law system like Indonesia, the principle of legal certainty can be found in practice in judicial institutions through a judge's decision. Decisions imposed by judges should ideally not cause new problems in the future in the community. That is, the quality of the judge's decision has an important influence on the environment in the community and also influences the authority and credibility of the court itself in addition to the Court's heavy duty in carrying out its functions and duties in accordance with people's conscience and dreams. Thus, the court institution is not only the engine of the law but also able to observe the nation's life intensely. Whereas in the common law tradition, the judiciary is more able to apply the principle of legal certainty because in the common law tradition there is a jurisprudence, meaning the previous judge's decision must bind the judge's decision afterward so that the same case with the same law will be decided equally.

Legal certainty in Indonesia has always been associated with the principle of legality, namely the principle in the provisions of Article 1 of the Criminal Code containing the principle of Asseln von Feuerbach or nullum delictum nulla poena sine praevia lege poenali. This principle is actualized in the formula: "No action can be punished except for the strength of the criminal rules in the regulations existing legislation, before the act is carried out". That means legal certainty requires a norm certain crimes, the norm must be based on legislation and non retroactive. 
Legal certainty stems from legal uncertainty created by its institution, some American legal experts such as Antony D'Amanto argue that the law leads to enormous uncertainty [9]. The role of the judge in interpreting, translating, and finding the law becomes very important so that there is no legal vacuum due to the non-functioning of the rule of law. Legal certainty is very closely related to standard and clear rules, or in other words, legal certainty relates to the implementation of legal rules in accordance with these rules. This goes back to the earlier explanation that legal certainty is the rule of law itself. Therefore, Legal Certainty can be measured by a lack of legal processes. Effective law is a fundamental law that can be renegotiated, this has similarities to the case approach (jurisprudence). However, legal certainty is not a legal requirement to the extent that it is not used to define law as a right.

Legal certainty also depends on the relationship between facts and law, three dimensions may emerge. First, there is certainty about the content of the law itself, namely certainty in legal material. Second, there is certainty about the transition from facts to law or in other words, procedural legal certainty. Third, there is the certainty that in forming a loop, linking the law with the facts and form of efficacy from legal certainty[10]. From the three dimensions above, it can be said that legal certainty occurs in conditions where the rule of law is in accordance with the reality of law enforcement itself.

In Indonesia, the principle of legal certainty is more applied in judicial institutions where judges prioritize laws and regulations on the outcome of the legislative process. In its development, the position of the court and judges in the Civil law system has several characteristics, namely: (a) the position and function of the judge are limited, the judge only functions to apply the law and may not make new laws; (b) the position of the judge as part of the judiciary is parallel to the legislature and executive. So, the branches of authorization must respect each other. The judge may not cancel the decision or legal product from another branch; (c) the judge is only a legal technician, so that all they can do is analyze the facts in the case handled then look for a law that is in accordance with that fact; (d) judges in the legal system Civil law is only one link in the government bureaucracy that carries out routinely assigned tasks.

Based on the characteristics above, it can be seen that the decisions produced by Indonesian judges are only editorial-juridical. As a matter of fact, judges think more in the scope of solutions to problems taken from systemic and authoritative expositions of the law and seek solutions using clauses and general principles. Even in the case of hoaxes, judges apply more to what is stipulated in the IET law than to explore the substantive truth of the case. Many cases of hoax spread are conducted using the formulations of Article 28 Paragraph (1) and (2) of the IET Law. Article 28 Paragraph (1) of the IET Law reads: Any person intentionally and without right of spreading false news and misleading consumers, which resulted in losses in Electronic Transactions. Related to the formulation of Article 28 paragraph (1) of the IET Law which uses the phrase "spreading false news", actually there are similar provisions in Article 390 of The Criminal Code although with a slightly different formula, the use of the phrase "broadcast the false news". Article 390 of the Criminal Code reads: Whoever intends to benefit himself or others by opposing the right to reduce or increase prices merchandise, fund or money securities with broadcast false news, sentenced to jail for two years eight months.

According to R. Soesilo in his book Kitab Undang-Undang Hukum Pidana (KUHP) serta Komentar-Komentarnya Lengkap Pasal Demi Pasal, the defendant can only be punished by Article 390 of the Criminal Code if it is found that the condition of Refresh news that it was a false report[11]. As for what is seen as false news, it not only tells empty news but also tells 
incorrectly about an event. So, this explanation should also apply to Article 28 paragraph (1) of the IET Law. News that tells incorrectly about an event is also a hoax.

Between that, Article 28 paragraph (2) of the IET Law states that Every person intentionally and without the right to disseminate information intended to cause hatred or hostility of certain individuals and/or groups based on ethnicity, religion, race, and intergroup (SARA). Actually, the purpose of this article is to prevent hostilities, riots, or even divisions based on SARA due to negative information that is provocative. The issue of SARA in the view of the community is a fairly sensitive issue. Therefore, this article is regulated in formal offenses and not material offenses. Examples of its application are if someone writes status in social networking information that contains provocations against certain tribes/religions with the intention of inciting the public to hate or commit anarchy against certain groups, then Article 28 paragraph (2) of this IET Law can be directly used by Law Enforcement Officials to ensnare the perpetrator who wrote the status. The criminal threat of Article 28 paragraph (2) of the IET Law is regulated in Article 45A paragraph (2) of the Act IET, namely: Anyone who intentionally and without the right to disseminate information aimed at arousing hatred or hostility of certain individuals and/or groups based on ethnicity, religion, race and intergroup (SARA) as referred to in Article 28 paragraph (2) is punished with criminal imprisonment of a maximum of 6 (six) years and / or a fine of at most 1 billion rupiahs.

\section{Hoax Cases In Indonesia: Dilemma Between Seeking Justice By Judge Decision And Legal Certainty In Indonesian Legal System}

\subsection{The "Rubber" Article from the IET Law}

The Government issued Law No. 11 of 2008 concerning Information and Electronic Transactions (IET) renewed by Law No. 19 of 2016. The IET Law was issued by the government because it realizes that the use of information technology, media, and communication has changed the behavior of people and human civilization globally. The progress of technology and information has positive and negative impacts as described above. In addition to contributing to the improvement of human well-being, progress, and civilization, the advancement of information technology has also become an effective means of lawlessness. The IET Law in its articles regulates signs related to rules and prohibitions that must be obeyed by the community when they interact in cyberspace or social media. Also included is what may be posted or prohibited from being displayed in cyberspace because it is feared that it can disrupt public order.

The existence of the IET Law has always been associated with freedom of expression [12]. This is because in the implementation of the IET Law has become a new threat to the protection of civil liberties in Indonesia, especially the freedom of opinion and expression. This situation arises due to the formulation of criminal norms of humiliation and defamation in the IET Law, as stipulated in Article 27 paragraph (3), which carries out criminal generalizations of insult. The provisions of Article 27 paragraph (3) which are considered often cause people to choose self-censorship for the socio-political and legal conditions that exist in the government and also society. The community becomes afraid to speak out about the injustice around them and yells at the violations committed the ruler for fear of being considered an insult or pollution good name. 
The Indonesian government realizes that the existence of globalization of technology has placed Indonesia as part of the world information society so that the establishment of the IET Law is carried out to protect, maintain and protect the public in the use of technology and information. The government is also aware that the use of technology and information plays an important role in national trade and economy to realize community welfare. There are several principles used in implementing this IET Law, including:

1. Principle of legal certainty. This means that the IET Law was established as a legal basis for the use of information technology and electronic transactions as well as everything that supports the implementation of legal recognition inside and outside the court.

2. Benefit Principle. This means that the principle for the use of information technology and electronic transactions is sought to support the information process so that it can improve people's welfare.

3. Principle of caution. This means that the basis for the parties concerned must pay attention to all aspects that have the potential to bring losses, both for themselves and for other parties in the use of information technology and electronic transactions.

4. Good faith principle. This means that the principle used by the parties in conducting and electronic transactions does not aim at intentionally and without rights or against the law resulting in losses to other parties without the knowledge of the parties.

5. The principle of freedom of choice in technology. This means that the use of information technology and electronic transactions is not focused on the use of certain technologies so that they can keep up with developments in the future.

When viewed from the principle and purpose, the IET Law is actually not intended to limit the freedom of expression of the people, especially on the internet. The IET Law is intended to provide security especially in conducting trade and commerce through internet media. However, the government actually inserts the "rubber article" of the IET Law, namely in Article 27 paragraph (1), (2), (3), and (4), Article 28 paragraph (1) and (2), and Article 29. Article 27 causes a person to be convicted of defamation, Article 28 causes a person to be convicted for spreading hoaxes, while Article 29 causes a person to be convicted for committing a threat. These articles actually have no causality with the initial goal of establishing the ITE Law, namely developing trade and the national economy in order to improve the welfare of the community. However, in its development, the articles were actually imposed on the public more for cases of insult and dissemination of hoaxes whose objects were government officials and legislative members.

\subsection{The dilemma between Seeking Justice by Judge Decision and Legal Certainty in Indonesian Legal System}

Indonesian people are faced with the fact that their freedom of expression or sharing an opinion in cyberspace is now restricted. The existence of several provisions in the IET Act can cause them to be jailed. The author notes, there are several articles in the IET Act that are quite dangerous, for example, Article 28 of the IET Act which can cause a person to be convicted for spreading hoaxes. In other hand, Article 29 in the IET Act can cause a person to be convicted of committing a threat. These articles actually have no causality with the initial goal of establishing the IET Act, namely developing trade and the national economy in order to improve the welfare of the community. However, in its development, these articles actually 
posed a threat to the freedom of opinion or expression of the people in the case of insulting and spreading hoaxes whose objects were government officials.

Based on the data released by the Ministry of Communication and Information (Kominfo) of the Republic of Indonesia, in 2018, there were at least 800,000 hoax sites in Indonesia [13]. This number is recorded to be enjoyed by around 132.7 million Indonesian people who are connected to the internet [13]. The majority of the hoax spreader sites utilize the high flow of internet users to access information and surf the internet. They use hoaxes as an effort to attract the attention of internet users (netizen) and increase the number of visitors to their web pages. With a high number of visitors, they can reap the rupiah coffers through advertising or selling their accounts for other business purposes.

Unfortunately, the attack on hoaxes in the cyberspace is not matched by the ability of the Indonesian people to anticipate and respond to the hoax. In a survey conducted by the Daily Social in 2018 and involving 2032 respondents, it showed that as many as $44.19 \%$ of respondents said they did not know how to anticipate hoaxes [14]. The results of the research also show that social media is still the biggest contributor to hoax information. Facebook (77.76\%), Whatsapp (72.93\%), and Instagram (60.24\%) became the big three social media applications that contributed to the spread of hoax information in Indonesia [14]. Of these, there were several cases which were later brought to the legal sphere to be tried and sentenced.

Miko Ginting, Researcher at the Center for Indonesian Law and Policy Studies/Pusat Studi Hukum dan Kebijakan (PSHK) stated that hoax spreaders could be subject to criminal sanctions in accordance with Article 14 and 15 of Act Number 1 of 1946 concerning Criminal Law Regulations with a prison sentence of 2 to 10 years. Meanwhile, if referring to the IET Law, hoax information disseminators can be subject to imprisonment sanctions and fines based on Article 27 paragraph (3), 28 paragraph 1 and paragraph (2). The criminal prison threat can reach 4 to 6 years and a fine of between 750 million and 1 billion rupiahs. Hoax information disseminators can also be subject to complaint offenses under Article 301 and 311 of the Criminal Code on the basis of defamation.

Especially for ASN/PNS (civil servants), these sanctions can increase if referring to Article 7 paragraph (2) and paragraph (3) of Government Regulation Number 53 of 2010 concerning Discipline of Civil Servants. Sanctions imposed can be in the form of a Light Discipline Penalty in the form of verbal reprimand until a Severe Discipline Penalty in the form of dismissal from an ASN/PNS (civil servants) status with disrespect. The many legal products that can trap these hoax spreaders often make judges confused and cannot carefully examine the evidence. This condition makes the judge's decision regarding the hoax case in Indonesia also less good and multiple interpretations.

For example, in the case of the spread of hoax information in Bandung, with the defendant Ahyad Saepuloh, where he was punished to 4 months 25 days in prison and a fine of 1 million rupiah by the Bandung District Court Judge on charges of violating Article 45 juncto Article 28 paragraph (2) Law Number 19 Year 2016 concerning Amendments to Law Number 11 Year 2008 concerning Information and Electronic Transactions or more well known as the IET Law. The Panel of Judges argued that the actions of the defendant disseminating hoax information regarding the persecution of Ustadz Prawoto relating to the rise of the Partai Komunis Indonesia (PKI) through Facebook social media, troubled the public. Elements that should be complied with in Article 28 paragraph (2) of the IET Law are elements that are intentional, without rights and cause hatred and hostility (provocation).

Textually, the IET Law does not provide an explanation of the three elements. Thus, referrals are often carried out by judges. Unfortunately, to prove whether the defendant committed his actions intentionally or not, the evidence tools are often not optimal. So, many 
judges ignore this element intentionally. Because, in fact, social media is a tool for selfexpression, where written status can appear accidentally as a response to an event. This situation is often not explored and cannot be proven by law enforcement officials, whether it is the Police, Prosecutors, or Judges who adjudicate.

In the case of the dissemination of information on other hoaxes, Rosyid Nur R. was sentenced to imprisonment for two years and six months and a fine of 50 million rupiahs a month in prison by the Panel of Judges of the Yogyakarta District Court. The defendant violated Article 45 A paragraph (2) of the IET Law. Previously, Sultan Hamengku Buwono X reported the defendant on charges of disseminating hoax information by displaying a photo of him, which could potentially lead to divisions and conflicts within the community. In relation to the use of Article 28 in conjunction with Article 45 of this IET Law, Indonesian Criminal Justice Reform (ICJR) considers that the IET Law is more often used to punish someone compared to similar legal products, for example, Law Number 40 of 2008 concerning the Elimination of Racial Discrimination. In fact, the substance actually contained is the same, only in the IET Law, the object is expanded by adding religion and between groups.

So, in this case, the judges of the judges are often prone to political problems, especially the politicization of religions and groups. Groups in this case who are often targeted are government officials. This means that many of the judges' decisions using these articles have a partiality to the government. Because, in some other cases, Law Enforcement Officials often do not follow up on hoaxes on the grounds that there are elements that are not met. For example, in the case of hoaxes for the release of Ustadz Abu Bakar Baasyir, the Esemka National Car production hoax, and so on.

\section{Conclusion}

In 2018, there were so many hoax cases that happen in Indonesia. The author notified that 7 (seven) case of hoax happens in Indonesia last year and grow up as a national trending topic. Based on data, the author found 3 (three) factors that caused several hoaxes that occur due to the emergence of social media, the existence of a kind of euphoria in using the social media and also the habit of most people who want to quickly share information.

Characteristic of the decisions produced by Indonesian judges are only editorial-juridical. It also found in some decisions about hoaxes by Indonesia judges. Even in the case of hoaxes, judges apply more to what is stipulated in the IET law than to explore the substantive truth of the case. Although, IET law has some rubber article that can be used by the government to jail the citizen. So, IET law nowadays is moving from the general purpose in the first time that the government made it. Because in its development, the articles were actually imposed on the public more for cases of insult and dissemination of hoaxes whose objects were government officials and legislative members

Acknowledgment. The authors would like to thank the Faculty of Law of the University of Muhammadiyah Malang and the Center for Research and Case Analyse of the Constitutional Court of the Republic of Indonesia which has supported morally and materially by sponsoring the conference and writing this paper.

\section{References}

[1] Z. F. Aditya and S. Al-Fatih, "Constitutional Rights of Indonesian Citizens in Expressing and 
Purposing Opinions on Internet in The Regime of The ITE Law," in 2nd International Summer Conference with the theme Human Rights In Souteast Asia: Are We Moving Backlward? Held by the Center for Human Rights, Multiculturalism, and Migration (CHRM2) University of Jember and Indonesian Consortium for Human Rights Scholar, 2017.

[2] T. McGonagle, "'Fake News': False fears or real concerns?," Netherlands Q. Hum. Rights, vol. 35, no. 4, pp. 203-209, 2017.

[3] M. Indonesia, "Hasil Survey Tetang Wabah Hoax Nasional," 2017.

[4] H. Allcott and M. Gentzkow, "Social Media and Fake News in the 2016 Election," J. Econ. Perspect., vol. 31, no. 2, pp. 211-236, 2017.

[5] O. $\quad$ Dictionari., $2017 . \quad$ [Online]. Available: https://en.oxforddictionaries.com/definition/hoax. [Accessed: 01-Mar-2019].

[6] L. Walsh, The Scientific Media Hoaxes of Poe, Twain, and Others. New York: State University of New York Press, 2006.

[7] A. Boese, The Museum of Hoaxes: The History of Outrageous Pranks and Deceptions. US: Penguin Group, 2002.

[8] A. Renda, "The Legal Framework to Address 'fake news': Possible Policy Actions at the EU Level, Policy Department for Economic, Scientific and Quality of Life Policies Author," 2018.

[9] A. D’Amato, “Legal Uncertainty," Calif. Law Rev. 71, vol. 71, pp. 1-55, 1983.

[10] R. . Lanneau, "What is Legal Certainty? A Theoretical Essay," 2013. [Online]. Available: https://ssrn.com/abstract=2361630. [Accessed: 01-Mar-2019].

[11] R. Soesilo, Kitab Undang-Undang Hukum Pidana (KUHP) Serta Komentar-Komentarnya Lengkap Pasal Demi Pasal. Bogor: Politeia, 1991.

[12] T. I. Institute, "Update Indonesia: Tinjauan Bulanan Ekonomi, Hukum, Keamanan, Politik, dan Sosial," The Indonesian Institute, vol. X, no. 12, 2016.

[13] Kominfo, "Ada 800.000 Situs Penyebar Hoax di Indonesia," 2019. [Online]. Available: http://kominfo.go.id/content/detail/12008/ada-800000-situs-penyebar-hoax-di-

indonesia/0/sorotan_media . [Accessed: 01-Mar-2019].

[14] R. Eka, "Hoax Distribution Trough Digital Platform in Indonesia 2018," 2018. [Online]. Available: https://dailysocial.id/report/post/hoax-distribution-through-digital-platforms-inindonesia-2018. [Accessed: 01-Mar-2019]. 